\title{
PENGARUH MOTIVASI DAN KEBIASAAN BELAJAR TERHADAP HASIL BELAJAR MATEMATIKA SISWA SMP NEGERI 5 WERA BIMA
}

\author{
Dusalan*1, Dewi Sartika*2 \\ ${ }^{1}$ Program Studi Pendidikan Matematika, STKIP Bima \\ Email: dusalanbima84@gmail.com
}

\begin{abstract}
ABSTRAK
Pengaruh Motivasi dan Kebiasaan Belajar terhadap Hasil Belajar Siswa SMP Negeri 5 Wera Bima. Jenis Penelitian ini adalah penelitian "ex-post facto". Tujuan penelitian ini adalah (1) apakah terdapat pengaruh positif motivasi belajar terhadap hasil belajar matematika siswa SMP Negeri 5 Wera Bima; (2) apakah terdapat pengaruh positif kebiasaan belajar terhadap hasil belajar matematika siswa SMP Negeri 5 Wera Bima; (3) apakah terdapat pengaruh positif secara bersama-sama (simultan) antara motivasi dan kebiasaan belajar terhadap hasil belajar matematika siswa SMP Negeri 5 Wera Bima. Populasi penelitian adalah siswa kelas III SMP Negeri 5 Wera Bima tahun pelajaran 2018/2019 dengan teknik pengambilan sampel adalah proporsional stratified random sampling. Teknik pengambilan data yaitu tes dan kuesioner. Penelitian ini dianalisis dengan statistik deskriptif nalisis statistik inferensial, hasil penelitian memberikan gambaran bahwa; (1) motivasi belajar berpengaruh positif terhadap hasil belajar siswa kelas III SMP Negeri 5 Wera Bima dengan kontribusi $R^{2}=80,55 \%$; (2) Kebiasaan belajar berpengaruh positif terhadap hasil belajar siswa kelas III SMP Negeri 5 Wera Bima dengan kontribusi $R^{2}=77,80 \%$; (3) Motivasi belajar dan kebiasaan belajar secara bersama-sama (simultan) berpengaruh positif terhadap hasil belajar siswa kelas III SMP Negeri 5 Wera Bima dengan kontribusi $\mathrm{R}_{\text {square }}^{2}=85,10 \%$, sementara sisanya sebesar $14,90 \%$.
\end{abstract}

Kata kunci: motivasi belajar, kebiasaan belajar, hasil belajar matematika 


\begin{abstract}
Effect of Motivation and Learning Habits on Student Learning Outcomes of Wera Bima 5 Middle School. This type of research is "ex-post facto" research. The purpose of this study is (1) whether there is a positive influence on learning motivation towards the mathematics learning outcomes of students of Wera Bima State Middle School 5; (2) whether there is a positive influence on learning habits on the mathematics learning outcomes of students of Wera Bima State Middle School 5; (3) whether there is a positive (simultaneous) effect between motivation and study habits on the mathematics learning outcomes of Wera Bima 5 Middle School students. The study population was third grade students of Wera Bima State Junior High School 5 in 2018/2019 with a sampling technique that was proportional stratified random sampling. Data collection techniques are tests and questionnaires. This study was analyzed by descriptive statistics inferential statistical analysis, the results of the study illustrate that; (1) learning motivation has a positive effect on the learning outcomes of class III students of SMP Negeri 5 Wera Bima with a contribution of $R^{2}=80.55 \%$; (2) Learning habits have a positive effect on the learning outcomes of class III students of SMP Negeri 5 Wera Bima with a contribution of $R^{2}=77.80 \%$; (3) Motivation to learn and study habits together (simultaneous) have a positive effect on the learning outcomes of class III students of SMP Negeri 5 Wera Bima with $R_{\text {square }}^{2}=85.10 \%$ contribution, while the remainder is $14.90 \%$.
\end{abstract}

Keywords: motivation to learn, study habits, learning outcomes in mathematics. 


\section{PENDAHULUAN}

\section{A. Latar Belakang}

Pendidikan pada dasarnya merupakan sesuatu yang dilakukan secara sadar untuk mengembangkan kepribadian dan kemampuan berpikir atau bernalar. Seseorang yang belajar selalu melibatkan kemampuan kognitif yang ada pada dirinya, dan juga kemampuan lain seperti : motivasi, kebiasaan belajar, penguasaan dan pengendalian diri, empati dan beberapa keterampilan sosial. Belajar banyak dipengaruhi oleh motivasi, baik dari dalam maupun dari luar diri seseorang. Oleh karena itu motivasi merupakan pendorong seseorang untuk melakukan kegiatan belajar sehingga dapat belajar matematika dengan baik untuk memperoleh nilai matematika yang tinggi.

Tinggi rendahnya motivasi belajar siswa dapat terlihat dari keadaan siswa pada saat mengikuti pembelajaran. Perhatian siswa pada saat pembelajaran berlangsung, seriusnya siswa mengerjakan tugas yang diberikan oleh guru, serta meningkatnya hasil belajar siswa merupakan faktor penilaian yang dapat dijadikan parameter dalam mengukur peningkatan motivasi belajar. Kebiasaan belajar turut pula memainkan peranan yang sangat penting bagi para siswa untuk memperoleh hasil belajar yang baik. Kecerdasan tidak dianggap sebagai faktor utama untuk mencapai sukses, namun intelegensi yang tinggi dan didukung kebiasaan belajar yang baik, dilandasi motivasi belajar yang kuat pasti akan medatangkan sukses dalam belajar.

Berkaitan dengan kenyataan yang dikemukakan di atas, dapat dikatakan bahwa hasil belajar matematika dipengaruhi oleh beberapa faktor, baik faktor dari dalam (internal) maupun faktor dari luar (eksternal). Oleh karena itu, faktor penyebab kesulitan siswa khususnya yang mempengaruhi hasil belajar matematika perlu diteliti secara sistematis, sehingga karakteristik siswa yang diduga mempunyai pengaruh terhadap hasil belajar matematika dapat ditelusuri secara lebih seksama. Hal ini menjadi fokus perhatian peneliti untuk mengungkapkan sejauh mana kontribusi atau pengaruh dari motivasi belajar dan kebiasaan belajar terhadap hasil belajar. Peneliti menyadari betapa pentingnya motivasi belajar dan kebiasaan belajar, untuk dikembangkan dalam pembelajaran, sehingga hasil belajar yang diharapkan dapat tercapai, sehingga peneliti dapat melaksanakan penelitian ini. 


\section{B. Rumusan Masalah}

Berdasarkan uraian maka dapat dirumuskan masalah dalam penelitian ini adalah:

1. Apakah terdapat pengaruh positif motivasi belajar terhadap hasil belajar matematika siswa SMP Negeri 5 Wera Bima?

2. Apakah terdapat pengaruh positif kebiasaan belajar terhadap hasil belajar matematika siswa SMP Negeri 5 Wera Bima?

3. Apakah terdapat pengaruh positif secara bersama-sama (simultan) antara motivasi dan kebiasaan belajar terhadap hasil belajar matematika siswa SMP Negeri 5 Wera Bima?

\section{TINJAUAN PUSTAKA}

\section{A. Motivasi Belajar}

Kata "motif" diartikan sebagai daya dorong atau penggerak seseorang untuk melakukan atau melaksanakan sesuatu. Berawal dari kata motif, maka motivasi adalah sebagai daya dorong atau penggerak dalam diri seseorang. Menurut Mc. Donald (dalam Saona, R. 2018: 20), Motivasi Adalah perubahan dari dalam diri seseorang yang ditandai dengan munculnya "feeling" dan didahului dengan tanggapan terhadap adanya tujuan. Dari pengertian tersebut motivasi mengandung tiga elemen penting yaitu perubahan energy, munculnya rasa/ feeling dan adanya tujuan.

\section{B. Kebiasaan Belajar}

Menurut Asih Pratiwi (dalam Saona, R. 2018:16) kebiasaan merupakan kegiatan sehari-hari yang dilakukan secara berulang-ulang dalam hal yang sama sehingga yang menjadi adat kebiasaan dan ditaati oleh masyarakat. Sedangkan menurut Djaali (2011:128) menyatakan bahwa kebiasaan belajar adalah cara belajar matematika yang biasa dilakukan secara berulang-ulang oleh siswa sehingga menjadi suatu kebiasaan setiap kali belajar, baik di dalam kelas maupun di luar kelas. Oleh karena itu, ketepatan belajar matematika yang dilakukan oleh siswa atau keseringan melakukan kebiasaan belajar matematika yang baik akan menentukan berhasil tidaknya dalam belajar matematika. Jadi dapat disimpulkan kebiasaan belajar merupakan sesuatu yang dilakukan sejak lama dan berulang-ulang untuk hal yang sama. Lebih lanjut diungkapkan oleh Haeranah, bahwa Kebiasaan belajar yang dilakukan di luar kelas meliputi beberapa faktor, antara lain : 1) Keteraturan dalam belajar, 2) Disiplin belajar, 3) Konsentrasi, 4) Pemantapan hasil belajar, 5) Penggunaan waktu belajar 


\section{Hasil Belajar}

Hasil belajar dapat dijelaskan dengan memahami dua kata yang membentuknya, yaitu "Hasil" dan "belajar". Pengertian hasil (product) menunjuk pada suatu perolehan akibat dilakukannya suatu aktivitas atau proses yang mengakibatkan berubahnya input secara fungsional. Sedangkan belajar dilakukan untuk mengusahakan adanya perubahan perilaku pada individu yang belajar. Perubahan perilaku itu merupakan perolehan yang menjadi hasil belajar. Hasil belajar adalah perubahan yang mengakibatkan manusia berubah dalam sikap dan tingkah lakunya (Winkel dalam Dusalan, 2013: 45)

\section{METODE PENELITIAN}

\section{A. Variabel Penelitian}

Variabel dalam penelitian ini adalah :

a. Hasil Belajar Matematika Siswa SMP Negeri 5 Wera Bima (Y)

b. Motivasi Belajar Siswa SMP Negeri 5 Wera Bima $\left(X_{1}\right)$

c. Kebiasaaan Belajar Siswa SMP Negeri 5 Wera Bima $\left(\mathrm{X}_{2}\right)$

\section{B. Paradigma Penelitian}

Adapun paradigma penelitiannya adalah :

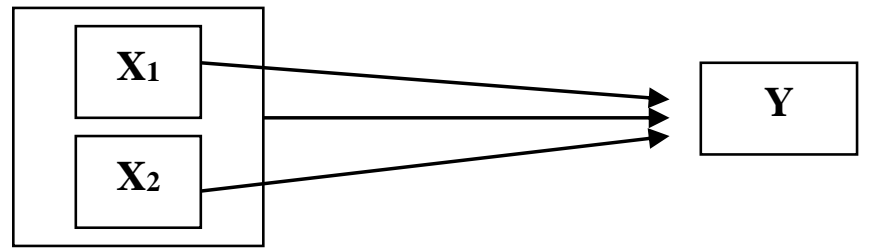

$\mathrm{X}_{1} \quad$ : Motivasi Belajar Siswa SMP Negeri 5 Wera Bima

$\mathrm{X}_{2} \quad$ : Kebiasaan Belajar Siswa SMP Negeri 5 Wera Bima

Y : Hasil Belajar Matematika Siswa SMP Negeri 5 Wera Bima

\section{Populasi dan Sampel Penelitian}

Populasi dalam penelitian ini adalah seluruh siswa kelas III SMP Negeri 5 Wera Bima tahun ajaran 2018/2019 sebanyak 215 orang, Teknik pengambilan sampel yang digunakan adalah proporsional stratified random sampling.

\section{Teknik Pengumpulan Data}


Untuk memperoleh skor variabel penelitian, digunakan tiga jenis instrumen, yaitu (1) tes hasil belajar matematika, (2) skala motivasi belajar, dan (3) skala kebiasaan belajar.

\section{HASIL DAN PEMBAHASAN}

\section{A. Hasil analisis statistika deskriptif}

Hasil analisis deskriptif yang berkaitan dengan skor variabel hasil belajar matematika siswa kelas III SMP Negeri 5 Wera Bima, menunjukkan bahwa skor rata-rata hasil belajar matematika siswa adalah 6,68 dari skor ideal 16 dengan standar deviasi 2,66. Distribusi skor responden memiliki skor terendah adalah 4 dan skor tertinggi adalah 12. Jadi dapat disimpulkan bahwa hasil belajar siswa kelas III SMP Negeri 5 Wera Bima tergolong sangat rendah. Sedangkan, Hasil analisis deskriptif untuk variabel motivasi belajar disajikan Hasil analisis deskriptif yang berkaitan dengan skor variabel motivasi belajar siswa kelas III SMP Negeri 5 Wera Bima, menunjukkan bahwa skor rata-rata motivasi belajar siswa adalah 55,56 dari skor ideal 58,2 dengan standar deviasi 8,10. Distribusi skor responden memiliki skor terendah adalah 15.08 dan skor tertinggi adalah 43,12. Jadi dapat disimpulkan bahwa motivasi belajar siswa kelas III SMP Negeri 5 Wera Bima tergolong tinggi. dan Hasil analisis deskriptif yang berkaitan dengan skor variabel kebiasaan belajar siswa kelas III SMP Negeri 5 Wera Bima, menunjukkan bahwa skor rata-rata kebiasaan belajar siswa adalah 30,28 dari skor ideal 53,16 dengan standar deviasi 9,80. Distribusi skor responden memiliki skor terendah adalah 11,38 dan skor tertinggi adalah 44,88. Jadi dapat disimpulkan bahwa kebiasaan belajar siswa kelas III SMP Negeri 5 Wera Bima tergolong sangat tinggi.

\section{B. Pengujian Hipotesis Penelitian}

\section{Pengaruh motivasi belajar terhadap hasil belajar matematika}

Untuk menguji hipotesis $H_{0}: \beta_{1}=0$ lawan $H_{1}: \beta_{1}>0$ dengan taraf signifikansi $\alpha=0,05$. sedangkan persamaan regresi yang diperoleh adalah $\hat{\mathrm{Y}}=-2,79+0,321 \mathrm{X}_{1}$. Hal ini menunjukkan bahwa hipotesis nol $\left(\mathrm{H}_{0}\right)$ ditolak, jadi dapat disimpulkan bahwa motivasi belajar siswa kelas III SMP Negeri 5 Wera Bima berpengaruh positif terhadap hasil belajar matematika. Nilai koefisien determinasi $\mathrm{R}_{\text {square }}^{2}=0,812$ atau sekitar $81,20 \%$ faktor motivasi 
belajar mempengaruhi hasil belajar matematika siswa kelas III SMP Negeri 5 Wera Bima tahun pelajaran 2018/2019.

\section{Pengaruh kebiasaan belajar terhadap hasil belajar}

Untuk menguji hipotesis $\mathrm{H}_{0}: \beta_{2}=0$ lawan $\mathrm{H}_{1}: \beta_{2}>0$ dengan taraf signifikansi $\alpha=0,05$. sedangkan persamaan regresi yang diperoleh adalah $\hat{\mathrm{Y}}=0,098+0,260 \mathrm{X}_{2}$, Hal tersebut menunjukkan bahwa hipotesis nol $\left(\mathrm{H}_{0}\right)$ ditolak, jadi dapat disimpulkan bahwa kebiasaan belajar siswa kelas III SMP Negeri 5 Wera Bima berpengaruh positif terhadap hasil belajar matematika, dengan nilai koefisien determinasi $\mathrm{R}_{\text {square }}^{2}=0,778$ atau sekitar $77,80 \%$.

\section{Pengaruh secara bersama-sama (simultan) motivasi belajara dan kebiasaan belajar terhadap hasil belajar matematika}

Untuk menguji hipotesis $\mathrm{H}_{0}: \beta_{1}=\beta_{2}=0$ lawan $\mathrm{H}_{1}: \beta_{1}>0$ atau $\beta_{2}>0$ dengan taraf signifikansi $\alpha=0,05$. sedangkan persamaan regresi yang diperoleh adalah $\hat{Y}=-1,33+$ $0,120 \mathrm{X}_{1}+0,191 \mathrm{X}_{2}$. Jadi menunjukkan bahwa hipotesis nol $\left(\mathrm{H}_{0}\right)$ ditolak, sehingga dapat disimpulkan bahwa motivasi dan kebiasaan belajar siswa kelas III SMP Negeri 5 Wera Bima tahun pelajaran 2018/2019. secara bersama-sama (simultan) berpengaruh positif terhadap hasil belajar matematika, dengan nilai koefisien determinasi $\mathrm{R}^{2}$ square $=0,851$ yang menunjukkan bahwa sekitar 85,10\% sementara sisanya sebesar 14,90\% dipengaruhi faktor-faktor lain yang tidak dapat dijelaskan dalam penelitian ini.

\section{Pembahasan Hasil Penelitian}

Hasil penelitian menunjukkan bahwa motivasi belajar siswa mempunyai pengaruh positif terhadap hasil belajar matematika siswa kelas III SMP Negeri 5 Wera Bima. Hal ini mendukung berbagai teori yang menunjukkan bahwa semakin tinggi motivasi belajar yang dimiliki siswa, maka semakin baik hasil belajar matematika siswa dan sebaliknya semakin rendah motivasi belajar siswa, maka semakin kurang hasil belajar siswa. Motivasi yang kuat membuat seseorang sanggup bekerja keras untuk mencapai sesuatu. Hal ini disebabkan oleh adanya dorongan dan optimisme yang tinggi sehingga memiliki semangat untuk melakukan aktivitas tertentu. 
Sedangkan untuk kebiasaan belajar siswa mempunyai pengaruh yang positif terhadap hasil belajar siswa kelas III SMP Negeri 5 Wera Bima. Hal ini mendukung berbagai teori yang menunjukkan bahwa semakin baik kebiasaan belajar siswa, maka semakin baik pula hasil belajarnya dan sebaliknya kebiasaan belajar yang buruk akan menyebabkan rendahnya hasil belajar siswa. Kebiasaan belajar matematika adalah cara belajar matematika yang biasa dilakukan secara berulang-ulang oleh siswa sehingga menjadi suatu kebiasaan setiap kali belajar, baik di dalam kelas maupun di luar kelas. Ketepatan belajar matematika yang dilakukan oleh siswa atau keseringan melakukan kebiasaan belajar matematika yang baik akan menentukan berhasil tidaknya dalam belajar matematika.

Hasil penelitian juga menunjukkan bahwa motivasi belajar yang tinggi yang diikuti dengan kebiasaan belajar yang baik mempunyai pengaruh yang signifikan terhadap hasil belajar siswa kelas III SMP Negeri 5 Wera Bima. Oleh karena itu dapat dikemukakan bahwa salah satu usaha yang dapat dilakukan untuk meningkatkan hasil belajar matematika siswa di sekolah adalah menumbuh kembangkan motivasi belajar dan memperbaiki kebiasaan belajar siswa. Seorang siswa yang memiliki motivasi tinggi cenderung melakukan kebiasaan belajar yang baik khususnya dalam pelajaran matematika, akan memberikan peluang besar untuk memperoleh nilai yang tinggi dari hasil belajarnya.

\section{KESIMPULAN}

Berdasarkan hasil pembahasan, maka dapat disimpulkan sebagai berikut:

1. Terdapat pengaruh positif motivasi belajar terhadap hasil belajar matematika siswa kelas III SMP Negeri 5 Wera Bima?

2. Terdapat pengaruh positif kebiasaan belajar terhadap hasil belajar matematika siswa kelas III SMP Negeri 5 Wera Bima?

3. Terdapat pengaruh positif secara bersama-sama (simultan) antara motivasi dan kebiasaan belajar terhadap hasil belajar matematika siswa kelas III SMP Negeri 5 Wera Bima? 


\section{DAFTAR PUSTAKA}

Djaali. 2011. Psikologi Pendidikan. Jakarta: Bumi Aksara

Dusalan. 2013. Kontribusi Konsep Diri, Perhatian Orang Tua dan Motivasi Berprestasi Terhadap Hasil Belajar Matematika. Tesis. Tidak diterbitkan. Makassar : Universitas Negeri Makassar

Fitri, L. 2013. Hubungan Motivasi Belajar dengan Prestasi Belajar Matematika pada siswa kelas VII SMPN 2 Tuntang Tahun Pelajaran 2012-2013. skripsi Tidak diterbitkan. Yogyakarta: FKIP Universitas Kristen Satya Wacana

Rasyid. H \& Mansyur. Penilaian Hasil Belajar. Bandung: CV Wacana

Riduwan . 2012. Belajar Mudah Penelitian. Bandung: Alfabeta

Riduwan \& Kuncoro, E. A., 2012. Path analysis. Bandung: Alfabeta

Saona, R. 2018. Hubungan Kebiasaan Belajar dan Motivasi Belajar dengan Prestasi Belajar siswa pada Mata Pelajaran Ekonomi di SMAN 2 Ngaglik. Laporan Hasil Penelitian tidak diterbitkan. Universitas Sanata Dharma Yogyakarta.

Sugiyono. 2011. Metode Penelitian Kuantitatif Kualitatif dan $R \&$ D. Bandung: Alfabeta

Sutrisnawati, N. 2012. Kontribusi Perhatian Orang Tua, Kebiasaan Belajar dan Kemampuan Guru dalam Mengelola Proses Pembelajaran Terhadap Prestasi Belajar Siswa pada Bidang Studi yang di-UAN-kan (Studi Persepsi siswa kelas XII SMAN 1 BLAHBATUH).

Uno, B. H. 2011. Teori Motivasi dan Pengukurannya. Jakarta: Bumi Aksara. 